\title{
Vascularization, Regeneration and Tissue Engineering
}

Guest Editors

Matthias W. Laschke, Homburg

Brigitte Vollmar, Rostock

\section{Contents}

Editorial

230 Vascularization, Regeneration and Tissue Engineering

Laschke, M.W. (Homburg); Vollmar, B. (Rostock)

Invited Review

232 Panta Rhei: Neovascularization, Angiogenesis and Nutritive Perfusion in Wound Healing

Sorg, H. (Dortmund); Tilkorn, D.J. (Essen); Mirastschijski, U. (Munich/Bremen); Hauser, J. (Essen); Kraemer, R. (Dortmund)

242 The Crucial Role of Vascularization and Lymphangiogenesis in Skin Reconstruction

Frueh, F.S.; Sanchez-Macedo, N.; Calcagni, M.; Giovanoli, P.; Lindenblatt, N. (Zurich)

255 Common Rodent Flap Models in Experimental Surgery

Schmauss, D.; Weinzierl, A. (Lugano/Munich); Schmauss, V. (Lugano); Harder, Y. (Lugano/Munich/Zurich)

265 Platelet-Rich Plasma in Tissue Engineering: Hype and Hope Lang, S. (Regensburg); Loibl, M. (Regensburg/Zurich); Herrmann, M. (Würzburg)

276 Cell Sheet-Based Vascularized Myocardial Tissue Fabrication Komae, H.; Ono, M.; Shimizu, T. (Tokyo)

286 The Arteriovenous Loop: Engineering of Axially Vascularized Tissue Weigand, A.; Horch, R.E.; Boos, A.M. (Erlangen); Beier, J.P. (Aachen); Arkudas, A. (Erlangen) 